\title{
Historical insights for understanding the emergence of community-based conservation in Kenya: international agendas, colonial legacies, and contested worldviews
}

\author{
$\underline{\text { Kasmira A. Cockerill }}^{1}$ and Shannon M. Hagerman ${ }^{1}$
}

\begin{abstract}
Community-based conservation (CBC) has emerged as a practical and ethical governance approach for seeking to balance development and biodiversity objectives. Yet, despite the important role of CBC for successfully meeting these objectives across scales, the historical context from which CBC arrangements arose is often underexamined. Critically examining the roots of current dilemmas, such as relating to knowledge, participation, and representation, informs current efforts to address the future of CBC. This article presents a historical analysis of the governance framework from which $\mathrm{CBC}$ arose in the context of wildlife conservation in Kenya, where over 60,000 square kilometers of land now falls under CBC. Based on document analysis, expert interviews, and six years in the field, we trace a set of key governance attributes from 1895 to 2016 and examine how and why they have changed (or not changed) through time. Attributes include governing authorities, policies, and legislation, actors involved, regulated user rights, and protected areas initiated. Through this analysis, we delineate five governance eras. Three interrelated findings are notable. First, colonial worldviews that perpetuate the idea of civilization separate from nature have persisted through the present and impact the role communities are granted within conservation. Second, the agendas of international conservation actors, often rooted in colonial worldviews, drive the conservation agenda and governance approaches via financial and political influence. Third, restricted representation and donor dependence continues to limit community authority in conservation decision making despite increased legal recognition. Despite these and other complexities relating to unreconciled issues of colonialism, elitism, and centralized control, CBC in Kenya continues to increase in conservation importance and total land contributed toward conservation. Although CBC holds promise for securing biodiversity objectives in human inclusive landscapes, historical legacies continue to shape how CBC is defined and experienced in local contexts and thus requires further attention to ensure long-term success.
\end{abstract}

Key Words: biodiversity conservation; community-based conservation; Kenya; wildlife policy

\section{INTRODUCTION}

Local and Indigenous communities have rarely been the primary benefactors or leaders of formal conservation (Western and Wright 1994, West et al. 2006, Kothari et al. 2013, KWCA 2016). Instead, communities have disproportionally borne the costs of conservation efforts to support wildlife on their lands (Western and Waithaka 2005, West and Brockington 2006, Greiner 2012). However today, Indigenous managed and/or owned protected areas make up an estimated $40 \%$ of all land formally recorded by governments globally (Garnett et al. 2018).

Community-based conservation (CBC) represents one response to ensure that communities are recognized, included, and benefit from conservation of wildlife and landscapes. CBC intends to address historical inequalities, injustices, and inabilities of statemandated conservation to adequately protect biodiversity (Nelson 2010, Schreckenberg et al. 2016). Proponents of CBC also promote the use and application of local and Indigenous knowledge and values, which have played critical roles in shaping habitat for wildlife through time (Berkes 2009, Lee 2016).

$\mathrm{CBC}$ is one approach amongst a broader array of communitycentered approaches sometimes referred to as Community-based Natural Resource Management, Indigenous and Local Community Conserved Areas or territories, among other names depending on geographical and political contexts (Barrow and Murphree 2001, Dressler et al. 2010). Here, we use the term CBC, a frequently used term in East Africa, to refer to nonstate conservation within formalized community institutions.

Despite the promises of $\mathrm{CBC}$, there is minimal agreement in the literature about its achievements and limitations (Agrawal and Redford 2006, Kothari et al. 2013, Galvin et al. 2018). Questions remain regarding the genuine inclusion of communities in $\mathrm{CBC}$ governance (Martin et al. 2016) and the realization of environmental or development objectives (Blaikie 2006, Shafer 2015), including socioeconomic benefits for participants (Pailler et al. 2015). We use a historical lens to identify the drivers of change in Kenyan conservation with an aim to understand the emergence of CBC approaches in this context. We do not question the current achievement or limitations of $\mathrm{CBC}$ but instead aim to understand the conditions that lead to the emergence of $\mathrm{CBC}$ and determine the current operational context of $\mathrm{CBC}$ in contemporary conservation.

Through an analysis of change through time (1895-2016) of actors involved, decision-making processes, formal rules, legal instruments and policies, as well as the outcomes in relation to rights and wildlife trends, we demonstrate how historical trends influence the expression of $\mathrm{CBC}$ in contemporary practice. We reveal the deep-rooted trends of contested worldviews, disproportionate influence of international actors, and weak accountability in formal structures that underpin many of the contested successes and challenges of CBC. In particular, non- 
African actors have driven significant changes in Kenyan conservation governance and contemporary conservation programs. Power and authority over conservation decisions remain deeply enmeshed in these historical relationships.

\section{THEORETICAL FOUNDATIONS}

We examine the emergence of CBC from an analytical viewpoint grounded in insights from the literature on political ecology (Jones 2006, Adams and Hutton 2007), discourse and the environment (Brosius 1999, Witter 2013), and social impacts of protected areas (West et al. 2006). Insights from these fields highlight the importance and disproportionate power of global actors and ideas in shaping conservation practice in particular locales (Calfucura 2018) including how specific conceptions of what counts as "natural" or "wild" can serve as legitimate injustices in the name of conservation (Cronon 1995, Neumann 1995), particularly for local and Indigenous communities (Pullin et al. 2013, Kelboro and Stellmacher 2015, Holmes and Cavanagh 2016).

Further, scholars working from historically oriented fields including environmental history (Davis 2009) have shown that complex environmental systems require attention beyond contemporary, localized indicators to adequately understand current practices (Mathevet et al. 2015). Accordingly, Kenya's relationship with wildlife is best understood not as a temporally isolated process, but rather as embedded within and produced by broader social, ecological, and political processes operating at multiple spatial and temporal scales (Damiens et al. 2017). Collectively, the fields described above implicate an analysis that focuses on actors, their objectives, connections to power (e.g. in decision making), and their rights and access over wildlife through time. Although much is known of the ecology and economics of conservation in Kenya (briefly reviewed below), the historical contours have not yet been empirically and systematically explored with regard to the noneconomic dimensions implicated above. Given the prominent role of wildlife in Kenya for global conservation, and the potential impacts for local and Indigenous communities, this remains a crucial gap in the literature, and one that we address here.

\section{BACKGROUND: COMMUNITY WILDLIFE CONSERVATION IN KENYA}

Although CBC can, and often does, addresses multiple aspects of nature and the environment, in the specific context of Kenyan conservation policy, wildlife has always been the central focus. We retain this focus on wildlife here. With this in mind, the literature on community conservation in Kenya can be characterized along three main lines of inquiry. First and foremost are ecologically focused investigations of species population declines, and proposed solutions to protect charismatic megafauna (primarily carnivores, elephants, and rhino). Research in this vein explores the relationship between wildlife numbers and conservancy establishment, primarily with positive correlations between the two (Ihwagi et al. 2015, Blackburn et al. 2016, Elliot and Gopalaswamy 2017, Ogutu et al. 2017). However, at the national scale, wildlife counts since 1977 suggest that population numbers in Kenya have decreased on average across major species by $68 \%$ between 1977 and 2016 (Ogutu et al. 2016). Ogutu et al. (2016) attribute the observed declines in part to wildlife legislation that continues to limit the involvement of communities.
A second line of inquiry focuses on economic evaluations of wildlife and Indigenous connections to landscapes (Emerton 1999, Norton-Griffiths and Said 2010, Nelson 2012). Scholarship in this realm highlights inequalities in the distribution of costs and benefits of conservation approaches. In Kenya, community participation and ownership of conservation enterprises has been argued as a required approach to incentivize the protection of wildlife (Western and Wright 1994, Western et al. 2009). This literature focuses primarily on the economic leverage of wildlife, often through ecotourism, employment, or direct payments, to motivate communities to protect and set aside land. Although the logic of this approach fits well under modern market-based solutions, many have argued that this strategy limits the ability to recognize and appreciate alternative values, knowledge, and traditional livelihoods practices defined by the community (Lee 2016). Accordingly, critics of CBC have pointed to the overcommodification of wildlife and natural resources as undermining the strengths of $\mathrm{CBC}$ approaches (Büscher and Dressler 2012, Bersaglio 2017).

A third line of inquiry examines the history of wildlife policy in Kenya. This literature provides the jumping off point for this study. Previous research on Kenya's national wildlife policy has tended to focus on one particular point in time, most commonly colonial policy (Kelly 1978), the transition into Kenya's independence in the late 1960s (Capone 1972, Maforo 1979, Ofcanskey 1981), and the contemporary role of the Kenya Wildlife Service (Waithaka 2012). These contributions emphasize the importance of policy mainly in regard to wildlife protection outcomes. Matheka's (2001, 2005, 2008) examinations of the social-ecological context of wildlife governance in Kenya from 1895 to 1975 offers the most comprehensive historical investigation to date. Kabiri (2007) presents one of the few contemporary insights into the centralized control of Kenya's wildlife institutions by examining wildlife policy through to 2006 . Despite the significant role that national wildlife policy has had on the economic, social, and cultural history of Kenya, a comprehensive study on the governance of wildlife conservation across the entire time frame of formal policy has not, until now, been conducted.

The objective of this paper is to describe the historical conditions over time in terms of actors, institutions, and outcomes that ultimately produced the conditions for and the emergence of community conservation in Kenya. We address two central questions: (1) How and why have a set of key conservation governance attributes changed over time in Kenya from 1895 to 2016? (2) How have these historical patterns and dynamics shaped contemporary conservation governance in Kenya, and the creation of community conservancies in particular?

\section{METHODS}

Following from the analytical foundations described above, we examine a set of key governance attributes often included in policy-oriented historical analyses of environmental systems (Davis 2009, Hagerman et al. 2010). Specifically, we examined actors, their objectives, connections to power (e.g., in decision making), rights and access over wildlife, and the formal rules and legal instruments in relation to national wildlife policy in Kenya from the creation of the British colony in 1895 to the contemporary independent government of 2016 (Table 1). We 
examined all formal strategies with the stated objective of conservation outcomes including state, private, and community approaches. State areas include any national park, reserve, or sanctuary managed by the government. Private conservation areas include lands owned by one person, family, or company with a self-declared conservation strategy. Community land includes land that is communally owned under trust, group ranch, or registered conservancy, and is recognized by the community of landowners, who actively participate in conservation of their land.

Table 1. Governance attributes investigated.

\begin{tabular}{ll}
\hline \hline Attribute & Aspect Queried \\
\hline Actors involved & Who are the decision makers? \\
& Who are the participants/people consulted? \\
& What are the stated objectives and desired \\
& outcomes of different actors? \\
& What problems or dilemmas concern different \\
& actors? \\
& Mechanism for inclusion or consultation \\
Decision-making process & Orchestrating power center \\
Formal rules, legal & Legal framework for wildlife ownership and \\
instruments, policies, and & management \\
property rights & Legal framework for land ownership and \\
& access \\
Outcomes & Rights and access over wildlife \\
& Amount of land under various conservation \\
& approaches \\
& Wildlife population trends
\end{tabular}

To examine the role of drivers originating at multiple scales, we pay attention to three scales of potential influence. First, we document global environmental trends, analyzing their influence on the development of Kenyan conservation policy, particularly the interests and priorities of major international donors and multinational nongovernmental organizations (NGOs). Second, we review Kenyan national wildlife institutions and the policies and legislation produced. Finally, we detail the expression of these trends and influences at the community level. Interactions between scales are explored to investigate the source of drivers of change.

\section{Data collection}

This study is based on document analysis of primary sources, indepth review of secondary academic literature, and semistructured interviews with nine expert informants. The first author collected data over the course of an eight-month field season in Kenya from May to December 2017. Primary documents considered in this analysis included conservation NGO reports, conference proceedings from major conservation meetings including the International Union for Conservation of Nature (IUCN), newspaper articles on new legislation or government appointments, official government reports, and all national conservation and wildlife policy documents from 1975 to 2016. Government documents include legislation passed into law, policy statements gazetted by the government, and draft policy or legislative working documents shared in public consultation. Policy documents from 1895 to 1974 were reviewed through secondary scholarly literature. Document analysis consisted of systematic coding facilitated by NVivo software (11.4.3 2018), following the governance attributes in Table 1. In total, 1080 pages were analyzed.
The first author also conducted nine in-depth, semistructured interviews. Interviewees were purposefully selected (Patton 2002) based on their current or past positions within government, legislative organizations, lobbying groups, NGOs, or Kenya Wildlife Service. These specialists had a minimum of 15 years working in Kenyan conservation and represent some of the most influential positions related to $\mathrm{CBC}$ and national wildlife policy. Interviewees were asked about their views on the conditions that contributed to the emergence of conservancies, and the role of NGOs within Kenyan conservation policy. All interviews were audio-recorded and transcribed verbatim for thematic analysis. Nvivo software facilitated an inductive, line-by-line coding analysis to identify emergent themes (Charmaz 2006). Interview findings added further context into the drivers of change through time and confirmed overall interpretations arising from the document analysis. Quotations from interviewees are used to illustrate key claims made in the analysis. To preserve confidentiality, interviewees are referred to by number and affiliation (e.g., \#4, NGO).

\section{A HISTORICAL PROFILE OF WILDLIFE GOVERNANCE AND CONSERVATION APPROACHES IN KENYA (1895- 2016)}

Below, we present five distinct governance eras for wildlife conservation in Kenya. The eras are delineated based on changes in the roles of influential actors, decision-making processes, legal policies, and legislation implemented, as well as key outcomes as identified through our analysis.

\section{Colonial wildlife policy (1895-1944)}

In 1895, the colonial British government began the implementation of formal wildlife policy in Kenya as the administrator of the protectorate. Ordinances were constructed to regulate the extraction of wildlife, control the trade in ivory, and enable game hunting for the white settlers (Waweru 2001, Steinhart 2006). Hunting concessions were maintained for the privileged elite including the archetypal explorer, the pioneer, and the trader (Maforo 1979), almost all of who were focused on big game hunting.

Game sanctuaries boundaries began the formation of official wildlife zones (for detailed analysis see Kelly 1978). Consultation with local peoples affected by the creation of game sanctuaries or hunting policies was rarely conducted during this era. Africans were excluded from hunting within game sanctuaries through laws that made it illegal to engage in traditional hunting practices and gain access to firearms. The Game Preservation Proclamation of 1920 explicitly stated that "natives" could not be granted hunting permits by local authorities and could only be granted access at the discretion of the governor (Maforo 1979). Colonial wildlife policy had little regard for local practices of livelihoods and methods of coexistence. Instead, the dominant view of the time was that nature existed as a pristine landscape without people. The colonial administration regarded traditional African customs and practices as primitive, and steeped in non-Christian ways that mismanaged the natural environment (Barrow and Fabricius 2002). Furthermore, the colonial approach of dividing land boundaries contributed to delineating ethnic lines within Indigenous communities, while preferential treatment of certain communities increased discontent between ethnic groups (Bonte and Galaty 1991, Waller and Sobania 1994). 
The Crown Land Ordinance of 1902 made all uninhabited land property of the Crown (Matheka 2001). This had devastating effects for many communities. In particular, nomadic pastoralists like the Maasai were manipulated into multiple agreements including the Maasai Agreement of 1904 and 1911, which forcibly removed communities from resource rich land (Hughes 2006). Much of this land was then gifted by the crown to European settlers to cultivate for industrial agriculture or cattle production. The appropriation of land by the crown based on "English proprietary principles" (Okoth-Ogendo 2003:110) began the dismantlement of the African commons.

The divide between local communities and the colonial administration eventually generated conflicts, notably between pastoralists and the game department. Disputes centered on grazing access for cattle and human-wildlife conflict. In one example, the Samburu District government of 1937 called for the destocking of Samburu cattle because of the perceived conflict with wildlife. Outraged, the Samburu chiefs threatened the government with their morans (warriors) and organized dances to demonstrate their resistance (Spencer 1973). The Samburu people demanded that wildlife be culled as well, resulting in 3000 , then 5000 zebras removed from the game reserve.

During this time, the British government in London was becoming increasingly concerned with wildlife protection. The United Kingdom was already a signatory to the Convention for the Preservation of Wild Animals, Birds and Fishes in Africa, which intended to reduce hunting permit numbers in colonial territories. However, the Game Department in Kenya was hampered by inefficiencies resulting in limited implementation of any external policy (Waithaka 2012). Unsatisfied with the British government's slow progress, a private organization known at the time as the Society for the Preservation of the Fauna of the Empire (SPFE, today Fauna and Flora International) began lobbying the British Government for more formal game sanctuaries (for a full account of SPFE's history see Prendergast and Adams 2003). In 1933 SPFE organized the Convention Relative to the Preservation of Fauna and Flora in the Natural State, which introduced the idea of national parks. The convention was organized in response to declining wildlife populations and the perception of failing conservation policy in many colonies (Neumann 1995). The SPFE saw the creation of national parks as a more permanent legislative solution to protect the foreign "Edens" (Anderson and Grove 1987). Although the reach of SPFE in the early 1900s rarely extended beyond European governments, the activities of SPFE marked the beginning of what would become a significant interest of British civil society in the conservation affairs of Africa.

These initial colonial policies set the stage for a particular way of knowing nature and conserving wildlife in Kenya over the next 100 years. First, the physical alienation of communities from nature and wildlife marked the beginning of wildlife custodianship as state-owned and managed. Second, the ideological separation of humans from nature, and particularly the alienation of local communities from their home environment, initiated the dominance of Western epistemologies and the colonial casting of African practices. Third, the allocation of land and prioritization of agriculture reduced space available for wildlife. It also intensified human-wildlife conflict by prioritizing nonwildlife compatible livelihood practices in areas of dense wildlife numbers. This included the state's disregard for pastoral communities despite evidence that the largest numbers of wildlife were found in areas where this was the primary livelihood practice. Finally, colonial policies opened the door for the prioritization of wildlife for the benefit of the tourist, foreigner, or as an export commodity without any regard for the role of nature in African culture, heritage, or subsistence utilization.

\section{National parks and independence (1945-1975)}

After years of controlled exploitation of wildlife, a transition by the local British colonial administration emerged in the 1940s, which supported a more preservationist approach to wildlife. The introduction of a national parks system had long been driven by SPFE (Anderson and Grove 1987). Although the Second World War had delayed efforts, there was international consensus supported by many conventions that national parks were the solution to stem wildlife loss (UNESCO Secretariat for the French Government 1948).

Mervyn Cowie was at the center of the public campaign for a national parks system in Kenya. Cowie was a district councilor in Nairobi from 1932 and in 1945 was appointed chairman of the National Parks Committee. Under Cowie's leadership, the national parks campaign was guided by the idea of the aesthetic value of nature. Cowie was one of the first to promote the value of a national parks system for the tourism industry. In his own memoirs, Cowie recounts his experiences of feeding lion cubs by hand to keep them nearby for high-profile visitors to see (Cowie 1961). He would use this opportunity to sell the idea of wildlife experiences at national parks in Kenya (Cowie 1961). External factors including the backing of colonial development funds and the increased economic viability of air travel helped make Cowie's vision of mass commercial tourism a reality (for a detailed account see Neumann 2002).

Cowie achieved his vision of a national parks system in 1945 when the ordinance was ratified by the government and a national park's board of trustees gazetted. At this point, land ownership broadly incorporated into three categories: crown land, which the governor could automatically declare a national park; African reserves, which needed the approval of the Native Lands Trust Board; and the White Highlands, which required approval from the Highlands Board (Matheka 2001). On the advice of the Game Policy Commission, the Kenya National Parks Trustees was set up to oversee the administration of national parks and parkadjacent areas (Steinhart 1989, Matheka 2005).

The National Parks Ordinance of 1945 marks the first time that the rights of local communities are mentioned in colonial wildlife policy. In theory, the creation of a national park in areas where communities resided required the approval of the Native Lands Trust Board, which was mandated to represent the interest of local communities. Although this created the first formal avenue for communities to reach the policy arena, there is little evidence that local interests were considered within colonial and state objectives (Kabiri 2007). Additionally, the allocated "native reserves" were contested lands and landscapes that rarely accurately represented one group of organized people (Fumagalli 1977). As a current senior wildlife government official described,

Kenya was a colony therefore the view, the consideration of the local people, was not taken into account. 


\begin{abstract}
Pronouncements and practices, they usually said you cannot do this, you as a local should not hunt now. Areas have been set aside as national parks and you cannot enter the national park. You cannot graze there. You cannot even draw water there. You cannot enter there by foot you must be in a $4 \times 4$ car. (\#9, Government)
\end{abstract}

In the early 1960s, as conflict between government and communities continued to increase, especially in the areas of Amboseli and Maasai Mara (detailed examples can be found in Kangwana 1993), the national parks trustees decided to hand over responsibility of Amboseli and Maasai Mara national parks to the respective local county councils (Ofcanskey 1981). Although communities were still rarely included in the forums of power and decision making, the resolution to entrust management of critical wildlife areas to a devolved government structure indicated the severity of issues associated with centralized control and the growing pressure to accommodate the needs of communities living with wildlife. The success of distributing power is debated (Galaty 1992). These areas would eventually be the first to develop extensive community conservation approaches adjacent to the reserves.

Prior to 1968, wildlife laws primarily strengthened the rights of private interests and the Crown. This left the majority of communities living on trust land that was controlled by the county councils (Odote 2013). In 1968 the government introduced the Land (Group Representatives Act), Chapter 287 (Republic of Kenya 1968), which was implemented in arid and semiarid pastoral lands to enforce communal land ownership structures for communities with shared grazing resources (Ogolla and Mugabe 1996).

International pressure for Kenya to preserve its wildlife only increased once independence was achieved in 1963. At the same time, concerns about the rights and interests of people affected by conservation activities began to take hold within the international wildlife agenda. In 1969 Kenya became a signatory to the African Convention on the Conservation of Nature and Natural Resources, which as a fundamental principle encouraged signatories to adhere to the interests of the people in natural resource management (Didi 2013).

The colonial ideology of wildlife and nature separate from humans was maintained in Kenyan policy upon independence. From 1963 to 1975 the majority of policies implemented by the British were maintained under the one-party national government. The only wildlife policy implemented during this period was Sessional Paper No. 3 of 1975 Statement on Future Wildlife Management (Republic of Kenya 1975), which forecast increasing tensions between agriculture, cattle production, and wildlife in land use policy. It states "The Government's fundamental goal with respect to wildlife is to optimize the returns from this resource, considering other forms of lands use" (1975:1) and prioritizing economic value "If wildlife is to continue to use some of this carrying capacity... it must yield returns to the ranchers which are at least equal to the returns from livestock" (1975:3).

\section{Centralized power (1976-1988)}

In 1976, Kenya introduced its first major legislation on wildlife and conservation policy since independence with the Wildlife
(Conservation and Management) Act (WCMA; Republic of Kenya 1977). The legislation, enacted in 1977, merged the Game Department and the Kenya National Parks Trustees into the Wildlife Conservation and Management Department (WCMD), centralizing all control of wildlife and conservation areas under the national government (Barrow et al. 2000). The 1977 WCMA legislation banned all hunting practices and most forms of consumptive uses of wildlife. The law was intended to address declines in wildlife, especially elephant and rhino, experienced across the county. The 1977 WCMA was followed by 1978 Ivory Ban, which centralized control of ivory: "Raw ivory is hereby declared to be a prohibited import and export and shall not be imported or exported by any person or organization other than the Government" (Republic of Kenya 1978). The 1977 WCMA and 1978 Ivory Ban presented the ideology that consumptive use of wildlife was "non-African" and changed the narrative of hunting associated with foreign sport hunting, into poaching, a crime carried out by Africans. This radically changed the meaning of killing an animal. It created the poacher as the enemy to wage war against. This narrative also accomplished the stigmatization of the consumption of "bushmeat" and traditional hunting practices.

The 1977 WCMA also introduced the concept of compensation for damage incurred by wildlife. This included the loss or damage of crops, property, livestock, personal injury, or death. Although compensation initially indicated acknowledgment of the need to manage human-wildlife conflict, the implementation of the legal framework of compensation was rarely effectively or efficiently managed. The loss of revenue from hunting focused all potential benefits from wildlife to tourism, limiting community access to benefits because of poorly devolved structures (Western and Waithaka 2005, Kabiri 2010a). These new policy ideas were developed with significant influence from large global funding bodies. As one senior conservationist recounts,

The World Bank said before we support both the wildlife program and the livestock program we want to see policies that reconcile these effectively, so that became the policy of 1977. (\#8, Kenya Wildlife Service [KWS])

With the introduction of the 1977 legislation, the World Bank issued a tourism and wildlife loan to Kenya of 1 million USD, today worth approximately 5 million. This loan was consistent with the international conservation community's shift in the late 1970 s and early 1980s to focus increasingly on sustainability (Adams 2001). The conservation community was beginning to address the historical misalignment of social development and preservation of wildlife. The Conservancy Strategy (IUCN 1980) set the course for integrated development and conservation programs and justified the significant flow of international aid from the developed world to the developing world under these new principles (Adams and Hutton 2007). This increased bilateral funding and the authority of NGOs in Kenyan conservation.

\section{Transitional period of contested benefits: era of KWS (1989- 2003)}

By the early 1990s the political climate in Kenya was shifting dramatically. Mounting international pressure and threats to remove international aid funding stimulated the weakening of 38 years de facto one-party state government. This marked the beginning of a democratic transition in Kenyan politics that saw 
increased participation of groups who had long been marginalized by former governments. In 1989 the government introduced an overhaul of the WCMA, which introduced a new parastatal called the Kenya Wildlife Service (KWS). Overall there was strong agreement across interviewees that the former "department was mismanaged and ineffective" (\#9, Government). Early KWS policy states "in the 15 years of its existence, the WCMD presided over the reduction of Kenya's elephant population by some $85 \%$, and its rhino population by $97 \%$ " (Kenya Wildlife Service 1990:3). KWS differed from the WCMA with the implementation of an independent board of trustees separate from the bureaucracy of the national government and increased militarization to combat wildlife crimes (Kabiri 2010b)

The new KWS parastatal was guided by the Zebra Book (KWS policy from 1991 to 1998). For the first time the wildlife arm of the government began implementing programs specifically supporting communities and conservation on land outside of national parks. Notable programs include "Parks beyond Parks" and the "Parks for Kenyans" campaigns, as well as the creation of the Community Wildlife Service, including revenue sharing programs (Waithaka 2012). These programs, coupled with growing support for landowner associations and investment opportunities for eco-tourism enterprises, encouraged the growth of community organization and participation in conservation (Baskin 1994).

\section{KWS sees wildlife management as an integral part of Kenya's national life, not something which goes on in isolation and often apparently in conflict with local interest. (Kenya Wildlife Service 1990:ix)}

In the mid-1990s with assistance from ongoing KWS programs, the creation of the first formal, independent community wildlife areas emerged. While KWS laid significant groundwork for community conservation development, changes to leadership in 1998 redirected priorities. Additionally, as many interviewees noted, "KWS was seen as a donor institution" (\#8, KWS), mandate driven by the funding it received. The reduction of KWS in community conservation programs left a vacuum of support that conservation NGOs quickly filled. As a local conservation expert in Northern Kenya described,

The AWFs [African Wildlife Foundation] and others, all they were doing is using money from overseas to do jobs in Africa, the community are recipients of their perception of conservation. (\#3, NGO)

Most new NGOs were involved in CBC in similar ways. First was the tourism management partner with the desire to develop tourism enterprises outside of national parks and reserves. Community areas were advantageous for new tourism products because they provided access to land with abundant wildlife without the technical restrictions imposed by formal protected areas. Second, with the poaching crises worse than ever, some $\mathrm{CBC}$ programs were initiated with a focus on fighting poaching and insecurity. Tensions between wildlife and people were high across the county and new incentive approaches were required to address human-wildlife conflict (Western et al. 2015). Last, but by no means least, communities began to demand more equitable benefit sharing and were seeking new ways to mitigate elite capture within old land governance structures. New conservation approaches supported by third-party NGOs offered fresh governance arrangements that many communities hoped would replace or overhaul corrupt and ineffective leadership in the Group Ranch Committees or Board of Trustees (for details on group ranch history see Galaty 1992). Each of these approaches created different types of conservancies that would contribute toward future diversity.

This explosion of conservation NGOs (Fig. 1) also attracted a variety of animal rights and welfare activists who became prominent actors in national conservation lobbying. Forums that organized these groups such as the Kenya Wildlife Working Group (KWWG) gained significant access to and influence over politicians, all the way to the president (Kabiri 2010b).

Fig. 1. Number of newly established conservation NGOs within each decade. Includes formally registered conservation and/or community development NGOs in Kenya with stated work in wildlife conservation. Dates established were taken from public government records or reported dates on organization's web site. The current decade from 2010 to 2016 has 11 newly established conservation NGOs.

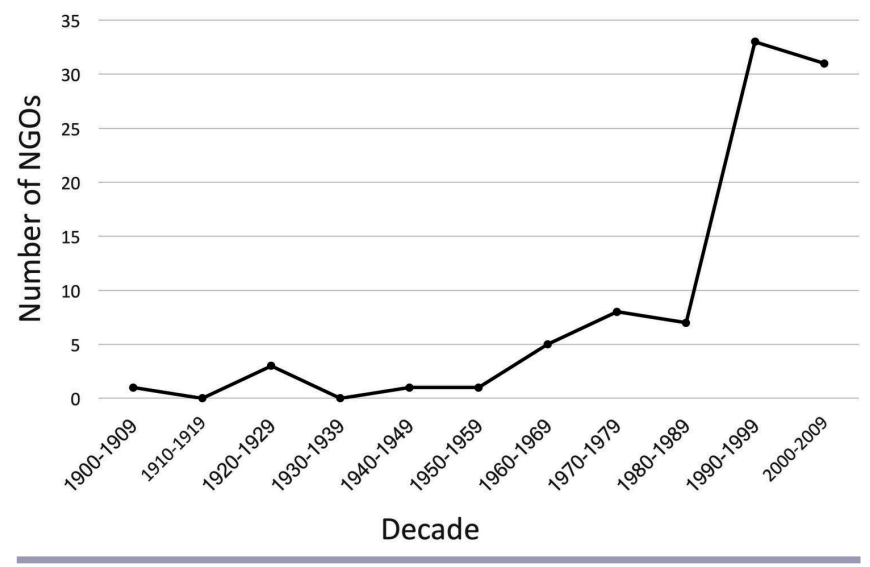

Internationally, Kenya adopted the Langkawi Declaration on the Environment in 1989. This was issued by the heads of the commonwealth counties and essentially promised aid and development money for a commitment to environmental sustainability. In the same year the Convention of the International Trade in Endangered Species (CITES) secured an international ban on ivory. In 1992 Kenya also became a signatory on the Convention on Biological Diversity.

\section{Emergence of legalized conservancies (2004-2016)}

The year 2004 marked the beginning of a string of failed attempts to amend Kenya's WCMA policies. The most well-known of these was the 2004 "GG" private member's parliament bill, named after the primary sponsor G. G. Kariuki, the Member of Parliament for Laikipia West (Laikipia West district was made up of a strong ranching constituent, descendants of many of the colonial land beneficiaries). The GG Bill brought to life the contested issue of wildlife as a public interest owned by the state utilizing private land (for detailed analysis of the bill see Kabiri 2010b). For the first time in wildlife policy the GG bill recommended comprehensive mobilization to devolve rights and benefits of wildlife to local communities who endured the cost of wildlife on 
Table 2. Comparison of legislative approaches between the 2004 and 2013 wildlife bills.

\begin{tabular}{|c|c|c|}
\hline Key Issue & 2004 “GG” Wildlife Bill (Failed) & 2013 Wildlife Act (Legislated) \\
\hline Legislation supporters & $\begin{array}{l}\text { Kenya Wildlife Working Group: community and } \\
\text { landowner forum. }\end{array}$ & Kenyan Wildlife Conservancies Association. \\
\hline Legislation opposition & $\begin{array}{l}\text { Kenya Coalition for Wildlife Conservation and } \\
\text { Management (KCWCM): animal rights/welfare } \\
\text { NGOs. }\end{array}$ & $\begin{array}{l}\text { Isolated organizations, none organized into a } \\
\text { representative organization. }\end{array}$ \\
\hline Compensation amendments proposed & $\begin{array}{l}\text { Increase in compensation specifically for wildlife } \\
\text { damages. }\end{array}$ & $\begin{array}{l}\text { Increases in compensation for human injuries, fatalities, } \\
\text { and damage to property. } \\
\text { Legalizes effective deterrence and control of problem } \\
\text { animals. } \\
\text { No time frame for implementation detailed. }\end{array}$ \\
\hline Consumptive use & $\begin{array}{l}\text { Relegalized utilization: there are some provisions for } \\
\text { wildlife on private land to acquire hunting permits. }\end{array}$ & $\begin{array}{l}\text { All consumptive uses of wildlife maintained as banned. } \\
\text { Hunting of all wildlife and the sale of species remains } \\
\text { illegal. } \\
\text { Bird shooting is made illegal. }\end{array}$ \\
\hline Kenya Wildlife Service (KWS) & $\begin{array}{l}\text { Restructuring KWS leadership to include } \\
\text { landowners. }\end{array}$ & \\
\hline Rights and access & $\begin{array}{l}\text { Increase in benefit sharing to landowner } \\
\text { associations. }\end{array}$ & $\begin{array}{l}\text { Land owners (private and community) have rights to } \\
\text { manage and use wildlife. }\end{array}$ \\
\hline Penalties and wildlife crime & & $\begin{array}{l}\text { Increases the severity of sentences upon conviction for } \\
\text { domestic wildlife crimes. }\end{array}$ \\
\hline
\end{tabular}

their lands. However, this attempt, and the many to follow would not pass into law. A former top KWS official explains the resistance to change in wildlife policy as boiling down to one problem: hunting.

\section{Every single time the issue of opening up the discussion to wildlife use of any form came up you had these huge lobbies, including from one of the US (sic) saying if Kenya is even considering or discusses hunting we will work very hard to get all tourism banned from coming into Kenya. (\#8, KWS)}

As such, wildlife reform through the 2000 s was hindered by very divided camps often unwilling to budge on key issues (Table 2). In fact, it was indicated by multiple interviewees that the reason the 2013 Act finally passed was "that there is nothing that looks like wildlife utilization in the policy" (\#1, NGO). For example, the Kenya Wildlife Conservancies Association (KWCA), a membership organization for conservancies formed in 2012, was able to lobby for many amendments in the 2013 Wildlife Act, except the amendments related to bird shooting.

Our organization for example, we proposed about 22 amendments that we wanted to see and I think out of that only 2 didn't make it, so that was quite a lot... one that didn't make it was on bird shooting. (\#5, NGO)

Although the 2013 Wildlife Act is regarded by many conservation actors, domestic and international, as a momentous step forward for community conservation, it has failed to devolve power and authority over wildlife in particular meaningful ways. KWS remains the sole body with mandated custodianship over wildlife. KWS's limited presence, constrained funding, and narrow mandate, especially in remote areas such as northern Kenya, continues to hamper any direct support of CBC. Interviewees generally agreed that within KWS "there isn't awareness of the strength of community, investing in community.” (\#3, NGO)
From 2004 to 2013 there was an $80 \%$ increase in the amount of land under conservation through nonstate conservation (Fig. 2). Most of this increase can be attributed to community conservation initiatives that account for $60.5 \%$ of all conservation areas by number in Kenya. However, there remained tension regarding how policy changes had initially benefitted individual, often white, landowners more than communities.

So that actually it [conservancies] becomes a tool in
delivering conservation, [and] delivering development to
the communities. And that is a bigger one to achieve
because it is quite amazing how because of our history,
our colonial history, a lot of people still think
conservancies are about some white Kenyans. (\#4, NGO)

During this era, international conservation actors were also moving forward with formal recognition of CBC. In 2003 the World Parks Congress (WPC) in Durban, South Africa adopted new resolutions that led to the formation of a new paradigm of social inclusion in protected areas (Brosius 2004, Adams and Hutton 2007). One of the stated objectives is the "enhancement of our core conservation goals, equitably integrating them with the interests of all affected people" (IUCN 2005:220). This resulted in the creation of IUCN protected area categories $\mathrm{V}$ and VI, which recognize protected areas for the preservation of natural and cultural interactions (category $\mathrm{V}$ ) and habitats with traditional systems and sustainable use (category VI). These changes correspond closely with an increase in CBC experiments across Kenya primarily funded by international conservation NGOs.

\section{DISCUSSION}

The 120-year history of policies shaping the utilization and preservation of wildlife in Kenya analyzed here brings into focus the asymmetrical power and influence of global, national, and local actors (Fig. 3). Until recently, the voices of local and Indigenous peoples have rarely had an avenue to influence wildlife policy. The effectiveness of CBC has often been assessed through 
Fig. 2. Total area under all types of formal conservation protection (national parks, national reserves, private conservation areas, and community conservation areas) compiled from the Kenya Wildlife Conservancies Association Membership and public data from International Livestock Research Institute, private web sites, Protected Planet, and National Government of Kenya documents.

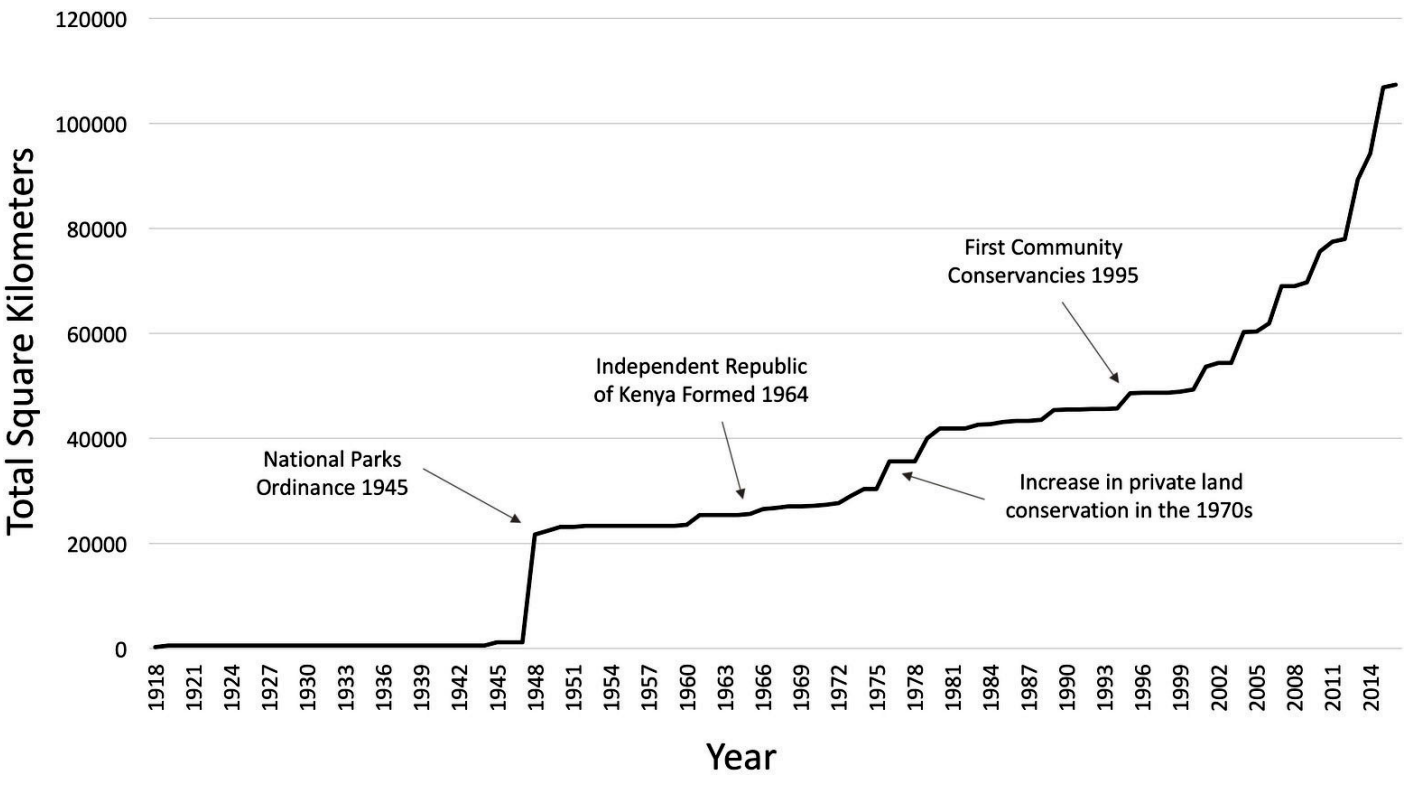

the lens of current capacity for communities to avoid the pitfalls of weak governance, elite capture, conflict, and perceptions of education and knowledge limitations (Homewood et al. 2012, Shafer 2015). In this paper we present an alternative lens from which to view the current capacity of communities in conservation by analyzing the long-rooted historical trends that influence the role and power communities have in determining conservation outcomes. The current shift to include communities in the conservation of wildlife did not emerge suddenly and the implications of these historical observations underscore three notable insights for understanding the emergence of community participation in wildlife policy in Kenya.

\section{Legacies of contested worldviews}

The trend toward $\mathrm{CBC}$ is driven by the principles of promoting, reintroducing, and prioritizing a return to a localized systemsbased approach of managing natural resources (Hulme and Murphree 1999, Berkes 2004). However, colonization presented a radically conflicting relationship with wildlife. By the colonial definition, nature existed only in the absence of people and was for the benefit (extraction, entertainment, or pleasure) of the privileged elite. By centralizing control of wildlife, through independence, the state continued to devalue local and Indigenous relationships with nature and wildlife as analyzed in the introduction of national park legislation in the mid-1970s. Conflicting worldviews have undermined principles of establishing CBC in Kenya and impeded the success of their implementation.

Although some have argued that conservation practice has gone through a paradigm shift (Adams and Hutton 2007) in terms of the approach to wildlife preservation, the historical analysis presented above suggests a much more complex situation in
Kenya. Current wildlife policy has maintained many of the systems and values that represent the colonial relationship with wildlife. A good example of this is the continual maintenance of prioritizing ranching and agricultural right over pastoral land rights. Historically entrenched views of land use and wildlife present significant barriers to overcome in order to recognize and reauthenticate local and Indigenous conservation approaches. Without the genuine recognition of communities' qualified role, autonomy, and rights to manage wildlife, future wildlife policy risks perpetuating colonial worldviews and continuing to legislate the separation of people and nature. Until local, traditional, and Indigenous values shape conservation strategies, any conservation approach will be an imposed ideology, limiting genuine community participation and ownership.

\section{The disproportionate influence of international organizations} International conservation organizations drive the expression of conservation in Kenya through the projects they fund and the ideas that underpin them. They also disproportionately shape international agreements and conventions on biodiversity, such as SPFE's role in the early 1900s all the way to big international NGO's funding KWS today. Their power continues to grow in Kenya. In 1990 there were on average five new conservation NGOs established every decade. Between 1990 and 2009 over 60 NGOs were established (Fig. 4, Table 3). This represents a $1100 \%$ increase. By implementing a conservation strategy with a dominant western value system, conservation practice is determining land use practices and directing cultural attachments (Espinosa-Romero et al. 2014). Prioritizing values perpetuated by those external to the system has effectively kept conservation within a colonial ideology. As Garland (2008:64) writes in her analysis of the role of Africans in wildlife conservation, "the 
Fig. 3. Historical time line, 1895-2016.

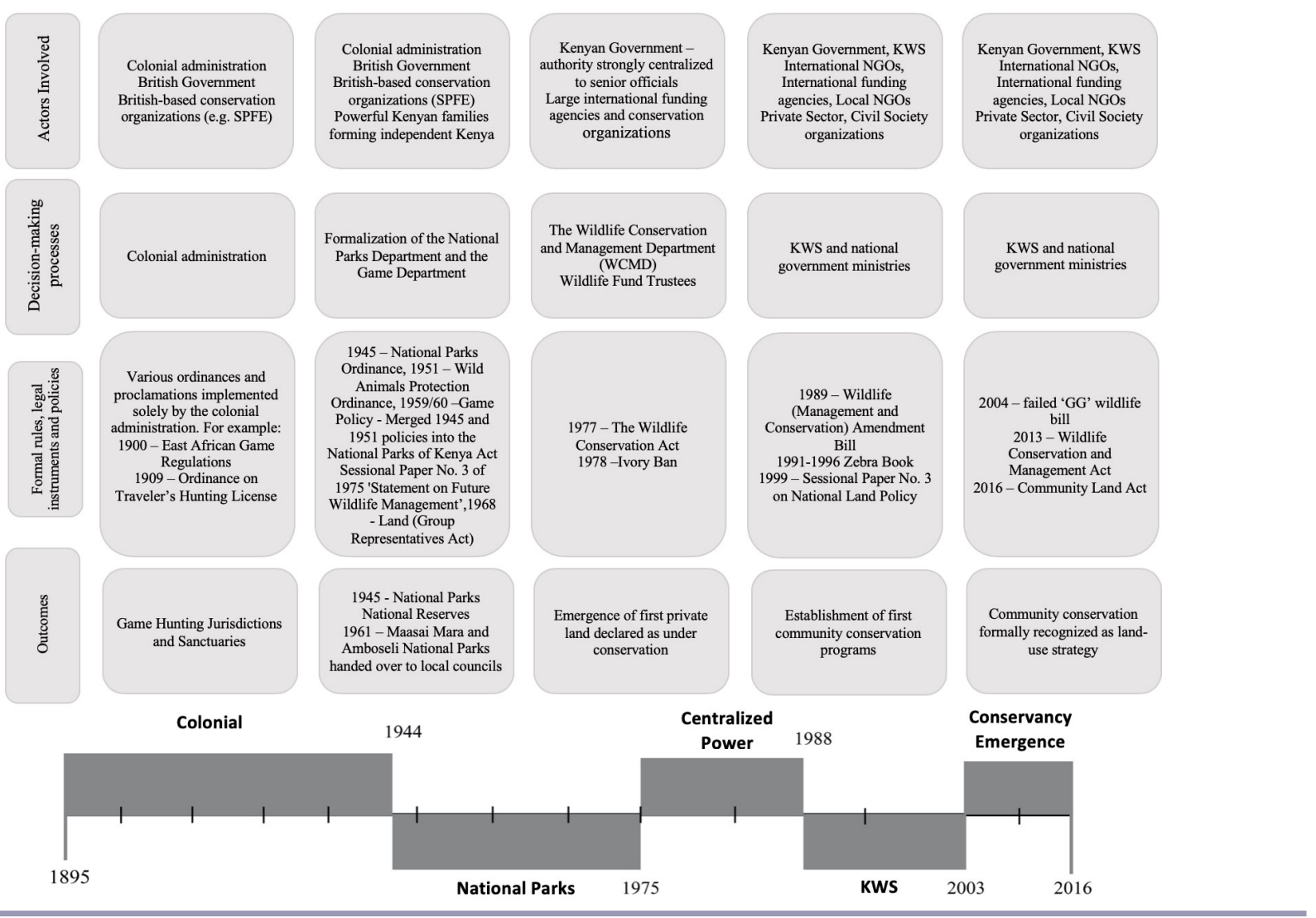

Fig. 4. Proportion of land under state, private, and community conservation approaches at important time points for Kenyan conservation policy.
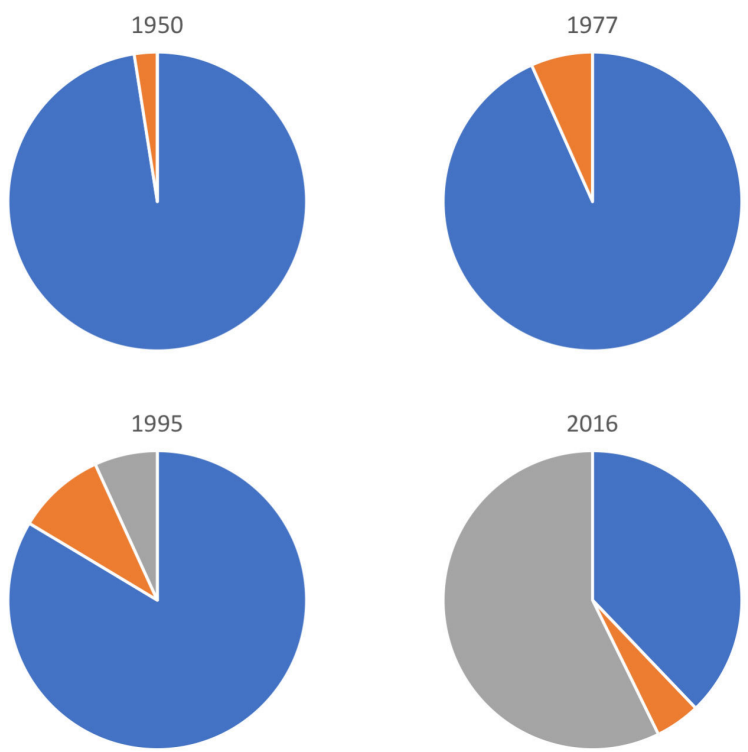

- State $n$ Private $\square$ Community
Table 3. Number of operational conservation areas under recognized conservation approaches at significant policy eras in Kenya.

\begin{tabular}{lcccc}
\hline \hline & 1950 & 1977 & 1995 & 2016 \\
\hline State & 8 & 25 & 42 & 43 \\
Private & 3 & 12 & 21 & 27 \\
Community & 0 & 0 & 6 & 107 \\
\hline
\end{tabular}

value of such spaces has been made fundamentally contingent on the desires and fantasy structures of people with a historically colonial relation to the continent of Africa."

The current influence of international NGOs and bilateral funding agencies suggests that Kenya has not yet been able to reconcile and address power inequities in terms of influence in shaping the agenda and directing priorities within conservation governance. This was explicitly stated throughout the conflicts arising in the many drafts of the 2013 Wildlife Conservation and Management Act (Republic of Kenya 2013) that were driven primarily by international funding agencies. Because of this influence and dominance, most CBC approaches in Kenya have not evolved beyond a system implemented by external interest in CBC. Rather, the power of the partner NGO or private sector has reinforced policy structures that serve to credit conservation success to external actors and limit the role of communities. 
Structures of power: accountability of institutions and devolution of authority

Despite efforts toward devolution, the participation of community actors remains limited in scope and influence. One of the systematic institutional flaws inherited from the colonial administration is the centralized, top-down approach to governance that creates barriers for participation. A centralized approach was maintained through independence because it benefited the selected elite who succeeded to power. Lack of accountability of the government to the people continues to allow corruption, inefficiencies, and ineffectiveness to plague government activities. Collectively, this has undermined any faith in the idea that the government and public institutions are accountable to the citizens of Kenya.

The lack of accountability of government to its constituents evokes authoritarian restrictions on the ability to implement even progressive policy (Kabiri 2007). Centralized control and limited local level planning for wildlife mistrust and distance between the state and the people, and has encouraged communities to look outside of government institutions to provide public and social services. Conservation NGOs have used this opportunity to develop new forms of community arrangements that incorporate conservation and development trade-offs. The best example of this is the number of conservancies that were established before conservancies were ever formally legislated (Fig. 2). This results in considerable power concentrated in internationally funded NGOs that would otherwise reside with democratically elected governments.

Although there have been notable changes in contemporary policy to attempt devolution of power, the same devolution process has not happened within the structure of KWS. The parastatal remains the centralized legal custodian of wildlife regardless of the ownership of land where wildlife resides. To support $\mathrm{CBC}$, KWS requires a realignment of structure, programs, and objectives in order to ensure wildlife remains central to the outcomes of CBC. The lack of accountability in both government and KWS has ultimately manifested in the creation of significant gaps between legislation passed and the implementation of these policies for communities.

\section{CONCLUSIONS AND POLICY IMPLICATIONS FOR THE FUTURE GOVERNANCE OF WILDLIFE IN KENYA}

The analysis of historical drivers in wildlife governance highlights at least three challenges and opportunities facing the future of wildlife policy in Kenya. First, CBC is not a conservation strategy independent of social considerations. In Kenya, conservancies are legally mandated by wildlife legislation, which limits the ability for conservancies to address issues of development and human needs. There is a need to integrate wider legislative support including agriculture, forestry, health, education, and infrastructure to work with community conservancy operations. The social complexity of conservancies, which current policy lacks the nuance and integration to support, has the potential to hinder avenues for government partnerships in CBC.

Second, devolution presents some contradictions in policy for CBC. Jurisdiction over planning and land management has been devolved to the county governments, however authority over wildlife remains centrally controlled by KWS and the national government. Benefits from wildlife at the national level are heavily focused on tourism yet locally tourism is not always possible or the best fit for the community. Dividing wildlife from land separates fundamental ecological considerations and narrows the potential options for valuing conservation and ensuring governments invest in local natural resource. Increasing the capacity of local governance, and ensuring policies support $\mathrm{CBC}$ across scales, will increase the community's ability to value and benefit from wildlife in ways that compliment and respect local customs, culture, and livelihoods.

Third, the lack of formal regulation by the government over conservancy development in Kenya for the last 25 years has allowed for the emergence of many localized solutions to complex problems (Galvin et al. 2018). This has resulted in a diversity of approaches to community conservation that look very different across the country. This local adaptation and national diversity should be viewed as a significant advantage, and a fruitful area for future research. Policy moving forward would benefit from fostering an environment where NGOs are encouraged to continue funding localized experiments and customized adaptation strategies. This would include increasing the acceptability for local actors to dictate funding terms instead of projects dictated by funding priorities.

Finally, looking forward, as $\mathrm{CBC}$ approaches continue to expand and evolve, the development of future legislation would benefit from integrating the lessons of historical events, drivers, and processes that have shaped past and present connections between people and land. This analysis has shown that CBC in Kenya has been shaped by unreconciled issues of colonialism, elitism, and bureaucratic centralized control, and the success of conservancies will be determined by local people's capacity to shift power dynamics. Thus, while new CBC approaches hold hope for securing biodiversity objectives in human inclusive landscapes, future legislation must protect the rights and authority of community landowners while encouraging productive frameworks for collaboration, engagement, and partnerships with a variety of allied actors.

Responses to this article can be read online at: http://www.ecologyandsociety.org/issues/responses. php/11409

\section{Acknowledgments:}

The research reported in this article was supported by a Strategic Recruitment Award from the Faculty of Forestry at the University of British Columbia. We wish to thank the interview participants who generously gave their time, insights, and expertise, as well as to the three anonymous reviewers for helpful comments on earlier drafts of this article. Finally, thanks to Hisham Zerriffi and Rob Kozak for comments on earlier versions of this paper as well as members of the Social-Ecological Systems Group at the Faculty of Forestry.

\section{LITERATURE CITED}

Adams, W. M. 2001. Green development: environment and sustainability in the Third World. Second edition. Routledge, London, UK. https://doi.org/10.4324/9780203440896 
Adams, W. M., and J. Hutton. 2007. People, parks and poverty: political ecology and biodiversity conservation. Conservation and Society 5(2):147-183.

Agrawal, A., and K. Redford. 2006. Poverty, development, and biodiversity conservation: shooting in the dark? Working Paper No. 26. Wildlife Conservation Society, Bronx, New York, USA. [online] URL: https://www.forest-trends.org/publications/povertydevelopment-and-biodiversity-conservation-shooting-in-the-dark/

Anderson, D., and R. H. Grove. 1987. Conservation in Africa: people, policies and practice. Cambridge University Press, New York, New York, USA. https://doi.org/10.1017/CBO9780511565335

Barrow, E., and D. Fabricius. 2002. Do rural people really benefit from protected areas - rhetoric or reality? Parks: The International Journal for Protected Area Managers 12(2):67-79.

Barrow, E., H. Gichohi, and M. Infield. 2000. Rhetoric or reality? A review of community conservation policy and practice in East Africa. International Institute for Environment and Development, London, UK. [online] URL http://pubs.iied.org/pdfs/7807IIED. pdf

Barrow, E. G. C., and M. Murphree. 2001. Community conservation from concept to practice: a practical framework. Pages 24-37 in D. Hulme and M. Murphree, editors. African wildlife and African livelihoods: the promise and performance of community conservation. James Currey, Oxford, UK.

Baskin, Y. 1994. There's a new wildlife policy in Kenya: use it or lose it. Science 265(5173):733-734. https://doi.org/10.1126/ science.265.5173.733

Berkes, F. 2004. Rethinking community-based conservation. Conservation Biology 18(3):621-630. https://doi.org/10.1111/ j.1523-1739.2004.00077.x

Berkes, F. 2009. Community conserved areas: policy issues in historic and contemporary context. Conservation Letters 2 (1):20-25. http://dx.doi.org/10.1111/j.1755-263X.2008.00040.x

Bersaglio, B. 2017. Green grabbing and the contested nature of belonging in Laikipia, Kenya: a genealogy. Dissertation. University of Toronto, Toronto, Ontario, Canada.

Blackburn, S., J. G. C. Hopcraft, J. O. Ogutu, J. Matthiopoulos, and L. Frank. 2016. Human-wildlife conflict, benefit sharing and the survival of lions in pastoralist community-based conservancies. Journal of Applied Ecology 53(4):1195-1205. http:// dx.doi.org/10.1111/1365-2664.12632

Blaikie, P. 2006. Is small really beautiful? Community-based natural resource management in Malawi and Botswana. World Development 34(11):1942-1957. https://doi.org/10.1016/j. worlddev.2005.11.023

Bonte, P., and J. Galaty. 1991. Herders, warriors, and traders: pastoralism in Africa. Westview, Boulder, Colorado, USA. https:// doi.org/10.4324/9780429045615

Brosius, J. P. 1999. Analyses and interventions: anthropological engagements with environmentalism. Current Anthropology 40 (3):277-310. https://doi.org/10.1086/200019

Brosius, J. P. 2004. Indigenous peoples and protected areas at the world parks congress. Conservation Biology 18(3):609-612. https://doi.org/10.1111/j.1523-1739.2004.01834.x
Büscher, B., and W. Dressler. 2012. Commodity conservation: the restructuring of community conservation in South Africa and the Philippines. Geoforum 43(3):367-376. http://dx.doi.org/10.1016/j. geoforum.2010.06.010

Calfucura, E. 2018. Governance, land and distribution: a discussion on the political economy of community-based conservation. Ecological Economics 145:18-26. http://dx.doi. org/10.1016/j.ecolecon.2017.05.012

Capone, D. 1972. Wildlife, man, and competition for land in Kenya, a geographical analysis. Dissertation. University of Michigan, Ann Arbor, Michigan, USA.

Charmaz, K. 2006. Constructing grounded theory: a practical guide through qualitative analysis. SAGE, Thousand Oaks, California, USA.

Cowie, M. 1961. I walk with lions: story of Africa's great animal preserves, The Royal National Parks of Kenya, as told by their first director. Macmillan and Co., London, UK.

Cronon, W., editor, 1995. Uncommon ground: rethinking the human place in nature. Norton \& Co., New York, New York, USA.

Damiens, F. L. P., L. Mumaw, A. Backstrom, S. A. Bekessy, B. Coffey, R. Faulkner, G. E. Garrard, M. J. Hardy, A. M. Kusmanoff, L. Mata, L. Rickards, M. J. Selinske, N. Torabi, and A. Gordon. 2017. Why politics and context matter in conservation policy. Global Policy 8(2):253-256. http://dx.doi.org/10.1111/17$\underline{58-5899.12415}$

Davis, D. K. 2009. Historical political ecology: on the importance of looking back to move forward. Geoforum 40(3):285-286. http:// dx.doi.org/10.1016/j.geoforum.2009.01.001

Didi, W. F. 2013. Devolution of wildlife management in Kenya to enhance community participation: an assessment of Kenyan legal frameworks. Thesis. University of Nairobi, Nairobi, Kenya.

Dressler, W., B. Büscher, M. Schoon, D. Brockington, T. Hayes, C. A. Kull, J. McCarthy, and K. Shrestha. 2010. From hope to crisis and back again? A critical history of the global CBNRM narrative. Environmental Conservation 37(1):5-15. http://dx.doi. org/10.1017/S0376892910000044

Elliot, N. B., and A. M. Gopalaswamy. 2017. Toward accurate and precise estimates of lion density. Conservation Biology 31:934-943. http://dx.doi.org/10.1111/cobi.12878

Emerton, L. 1999. The nature of benefits and the benefits of nature: why wildlife conservation has not economically benefitted communities in Africa. Institute for Development Policy and Management, University of Manchester, UK. [online] URL: https://www.cbd.int/financial/values/g-benefitsafricamunity-iucn. pdf

Espinosa-Romero, M. J., L. F. Rodriguez, A. H. Weaver, C. Villanueva-Aznar, and J. Torre. 2014. The changing role of NGOs in Mexican small-scale fisheries: from environmental conservation to multi-scale governance. Marine Policy 50:290-299. https://doi.org/10.1016/j.marpol.2014.07.005

Fumagalli, C. T. 1977. A diachronic study of change and sociocultural processes among the pastoral nomadic Samburu of Kenya 
1900-1975. Dissertation. State University of New York, Albany, New York, USA.

Galaty, J. 1992. "The land is yours": social and economic factors in the privatization, sub-division and sale of Maasai ranches. Nomadic Peoples 30:26-40.

Galvin, K. A., T. A. Beeton, and M. W. Luizza. 2018. African community-based conservation: a systematic review of social and ecological outcomes. Ecology and Society 23(3):39. https://doi. org/10.5751/ES-10217-230339

Garland, E. 2008. The elephant in the room: confronting the colonial character of wildlife conservation in Africa. African Studies Review 51(3):51-74. https://doi.org/10.1353/arw.0.0095

Garnett, S. T., N. D. Burgess, J. E. Fa, Á. Fernández-Llamazares, Z. Molnár, C. J. Robinson, J. E. M. Watson, K. K. Zander, B. Austin, E. S. Brondizio, N. F. Collier, T. Duncan, E. Ellis, H. Geyle, M. V. Jackson, H. Jonas, P. Malmer, B. McGowan, A. Sivongxay, and I. Leiper. 2018. A spatial overview of the global importance of Indigenous lands for conservation. Nature Sustainability 1:369-374. https://doi.org/10.1038/s41893-018-0100-6

Greiner, C. 2012. Unexpected consequences: wildlife conservation and territorial conflict in northern Kenya. Human Ecology 40:415-425. https://doi.org/10.1007/s10745-012-9491-6

Hagerman, S. M., H. Dowlatabadi, and T. Satterfield. 2010. Observations on drivers and dynamics of environmental policy change: insights from 150 years of forest management in British Columbia. Ecology and Society 15(1):2. https://doi.org/10.5751/ es-03073-150102

Holmes, G., and C. J. Cavanagh. 2016. A review of the social impacts of neoliberal conservation: formations, inequalities, contestations. Geoforum 75:199-209. https://doi.org/10.1016/j. geoforum.2016.07.014

Homewood, K. M., P. C. Trench, and D. Brockington. 2012. Pastoralist livelihoods and wildlife revenues in East Africa: a case for coexistence? Pastoralism 2:19. https://doi.org/10.1186/2041-7136-2-19

Hughes, L. 2006. Land alienation and contestation in Kenyan Maasailand. International Association for the Study of the Commons Conference, Bogor Agricultural University, Indonesia. [online] URL https://dlc.dlib.indiana.edu/dlc/bitstream/handle/10535/8915/ HUGHES 0880.pdf?s

Hulme, D., and M. Murphree. 1999. Communities, wildlife and the 'new conversation' in Africa. Journal of International Development 11(2):277-285.

Ihwagi, F. W., T. Wang, G. Wittemyer, A. K. Skidmore, A. G. Toxopeus, S. Ngene, J. King, J. Worden, P. Omondi, and I. Douglas-Hamilton. 2015. Using poaching levels and elephant distribution to assess the conservation efficacy of private, communal and government land in northern Kenya. PLoS ONE 10(9):e0139079. https://doi.org/10.1371/journal.pone.0139079

International Union for the Conservation of Nature and Natural Resources (IUCN). 1980. World conservation strategy: living resource conservation for sustainable development. IUCN, Geneva, Switzerland.
International Union for the Conservation of Nature and Natural Resources (IUCN). 2005. Benefits beyond boundaries Report of the Vth IUCN World Parks Congress. IUCN, Bland, Switzerland.

Jones, S. 2006. A political ecology of wildlife conservation in Africa. Review of African Political Economy 33(109):483-495. https://doi.org/10.1080/03056240601000911

Kabiri, N. 2007. Global environmental governance and communitybased conservation in Kenya and Tanzania. Dissertation. University of North Carolina at Chapel Hill, North Carolina, USA.

Kabiri, N. 2010a. The political economy of wildlife conservation and decline in Kenya. Journal of Environment and Development 19(4):424-445. https://doi.org/10.1177/1070496510384463

Kabiri, N. 2010b. Historic and contemporary struggles for a local wildlife governance regime in Kenya. Pages 121-144 in F. Nelson, editor. Community rights, conservation and contested land. Earthscan, New York, New York, USA.

Kangwana, K. 1993. Elephants and Maasai: conflict and conservation in Amboseli, Kenya. Dissertation. University of Cambridge, Cambridge, UK.

Kelboro, G., and T. Stellmacher. 2015. Protected areas as contested spaces: Nech Sar National Park, Ethiopia, between 'local people', the state, and NGO engagement. Environmental Development 16:63-75. https://doi.org/10.1016/j.envdev.2015.06.005

Kelly, N. 1978. In wildest Africa: the preservation of game in Kenya, 1895-1933. Dissertation. Simon Fraser University, Vancouver, British Columbia, Canada.

Kenya Wildlife Service. 1990. A policy framework and development programme 1991-1996. Kenya Wildlife Service, Nairobi, Kenya.

Kenyan Wildlife Conservancies Association (KWCA). 2016. Community conservancy policy support and implementation program. KWCA, Nairobi, Kenya.

Kothari, A., P. Camill, and J. Brown. 2013. Conservation as if people also mattered: policy and practice of community-based conservation. Conservation and Society 11(1):1-15. http://dx.doi. org/10.4103/0972-4923.110937

Lee, E. 2016. Protected areas, country and value: the natureculture tyranny of the IUCN's protected area guidelines for Indigenous Australians. Antipode 48(2):355-374. http://dx.doi. org/10.1111/anti.12180

Maforo, D. D. 1979. Black-White relations in Kenya game policy: a case study of the Coast Province, 1985-1956. Dissertation. Syracuse University, Syracuse, New York, USA.

Martin, A., B. Coolsaet, E. Corbera, N. M. Dawson, J. A. Fraser, I. Lehmann, and I. Rodriguez. 2016. Justice and conservation: the need to incorporate recognition. Biological Conservation 197:254-261. http://dx.doi.org/10.1016/j.biocon.2016.03.021

Matheka, R. 2001. The political ecology of wildlife conservation in Kenya, 1895-1975. Dissertation. Rhodes University, Grahamstown, South Africa. 
Matheka, R. 2005. Antecedents to the community wildlife conservation programme in Kenya, 1946-1964. Environment and History 11(3):239-267. https://doi.org/10.3197/096734005774434539

Matheka, R. M. 2008. Decolonisation and wildlife conservation in Kenya, 1958-68. Journal of Imperial and Commonwealth History 36(4):615-639. http://dx.doi.org/10.1080/03086530802561016

Mathevet, R., N. L. Peluso, A. Couespel, and P. Robbins. 2015. Using historical political ecology to understand the present: water, reeds, and biodiversity in the Camargue Biosphere Reserve, southern France. Ecology and Society 20(4):17 http://dx.doi. org/10.5751/ES-07787-200417

Nelson, F. 2010. Community rights, conservation and contested land. Earthscan, Washington, D.C., USA. https://doi. org/10.4324/9781849775052

Nelson, F. 2012. Natural conservationists? Evaluating the impact of pastoralist land use practices on Tanzania's wildlife economy. Pastoralism: Research, Policy and Practice 2:15. https://doi. org/10.1186/2041-7136-2-15

Neumann, R. P. 1995. Ways of seeing Africa: colonial recasting of African society and landscape in Serengeti National Park. Ecumene 2(2):149-169. https://doi.org/10.1177/147447409500200203

Neumann, R. P. 2002. The postwar conservation boom in British Colonial Africa. Environmental History 7(1):22-47. https://doi. org/10.2307/3985451

Norton-Griffiths, M., and M. Y. Said. 2010. The future for wildlife on Kenya's rangelands: an economic perspective. Pages 367-392 in J. Du Toit, R. Kock, and J. Deutsch, editors. Wild rangelands: conserving wildlife while maintaining livestock in semi-arid ecosystems. Wiley-Blackwell, Chichester, UK. https://doi. org/10.1002/9781444317091.ch14

Odote, C. 2013. The dawn of Uhuru? Implications of constitutional recognition of communal land rights in pastoral areas of Kenya. Nomadic Peoples 17(1):87-105. https://doi. org/10.3167/np.2013.170105

Ofcanskey, T. P. 1981. A history of game preservation in British East Africa 1895-1963. Dissertation. West Virginia University, Morgantown, West Virginia, USA.

Ogolla, B. D., and J. Mugabe. 1996. Land tenure systems and natural resources. Pages 85-116 in J. B. Ojwang and C. Juma, editors. In land we trust: environment, private property and constitutional changes. Initiative, Nairobi, Kenya.

Ogutu, J. O., B. Kuloba, H.-P. Piepho, and E. Kanga. 2017. Wildlife population dynamics in human-dominated landscapes under community-based conservation: the example of Nakuru Wildlife Conservancy, Kenya. PLoS ONE 12(1):e0169730. http:// dx.doi.org/10.1371/journal.pone.0169730

Ogutu, J. O., H.-P. Piepho, M. Y. Said, G. O. Ojwang, L. W. Njino, S. C. Kifugo, and P. W. Wargute. 2016. Extreme wildlife declines and concurrent increase in livestock numbers in Kenya: what are the causes? PLoS ONE 11(9):e0163249. http://dx.doi. org/10.1371/journal.pone.0163249

Okoth-Ogendo, H. W. O. 2003. The tragic African commons. University of Nairobi Law Journal I:107-117.
Pailler, S., R. Naidoo, N. D. Burgess, O. E. Freeman, and B. Fisher. 2015. Impacts of community-based natural resource management on wealth, food security and child health in Tanzania. PLoS ONE 10(7):e0133252. http://dx.doi.org/10.1371/ journal.pone.0133252

Patton, M. Q. 2002. Qualitative research and evaluation methods. Third edition. SAGE, Thousand Oaks, California, USA.

Prendergast, D. K., and W. M. Adams. 2003. Colonial wildlife conservation and the origins of the Society for the Preservation of the Wild Fauna of the Empire (1903-1914). Oryx 37 (2):251-260. https://doi.org/10.1017/s0030605303000425

Pullin, A. S., M. Bangpan, S. Dalrymple, K. Dickson, N. R. Haddaway, J. R. Healey, H. Hauari, N. Hockley, J. P. G. Jones, T. Knight, C. Vigurs, and S. Oliver. 2013. Human well-being impacts of terrestrial protected areas. Environmental Evidence 2:19. http:// dx.doi.org/10.1186/2047-2382-2-19

Republic of Kenya. 1968. Land (Group Representatives Act). Republic of Kenya, Nairobi, Kenya.

Republic of Kenya. 1975. Sessional Paper No. 3 of 1975 Statement on Future Wildlife Management. Republic of Kenya, Nairobi, Kenya.

Republic of Kenya. 1977. Wildlife (Conservation and Management) Act. Republic of Kenya, Nairobi, Kenya.

Republic of Kenya. 1978. Wildlife (conservation and management) (control of raw ivory) Regulations. Republic of Kenya, Nairobi, Kenya.

Republic of Kenya. 2013. The Wildlife Conservation and Management Act. Republic of Kenya, Nairobi, Kenya.

Schreckenberg, K., P. Franks, A. Martin, and B. Lang. 2016. Unpacking equity for protected area conservation. Parks 22:2. https://doi.org/10.2305/IUCN.CH.2016.PARKS-22-2KS.en

Shafer, C. L. 2015. Cautionary thoughts on IUCN protected area management categories V-VI. Global Ecology and Conservation 3:331-348. http://dx.doi.org/10.1016/j.gecco.2014.12.007

Spencer, P. 1973. Nomads in alliance. Symbiosis and growth among the Rendille and Samburu of Kenya. Oxford University Press, Oxford, UK.

Steinhart, E. I. 1989. Hunters, poachers and gamekeepers: towards a social history of hunting in colonial Kenya. Journal of African History 30(2):247-264. https://doi.org/10.1017/ $\underline{\mathrm{S} 0021853700024129}$

Steinhart, E. I. 2006. Black poachers, white hunters: a social history of hunting in colonial Kenya. Oxford University Press, Oxford, UK.

UNESCO Secretariat for the French Government. 1948. Conference for the Establishment of the International Union for the Protection of Nature. UNESCO Secretariat for the French Government, Fontainebleau, France.

Waithaka, J. 2012. Historical factors that shaped wildlife conservation in Kenya. George Wright Forum 29(1):21-29.

Waller, R., and N. W. Sobania. 1994. Pastoralism in historical perspective. Pages 45-68 in E. Fratkin, K. Galvin, and E. A. Roth, 
editors. African pastoralist systems: an integrated approach. Lynne Rienner, London, UK.

Waweru, P. 2001. Frontier urbanisation: the rise and development of towns in Samburu District, Kenya, 1909-1940. Azania: Archaeological Research in Africa 36-37(1):84-97. https://doi. org/10.1080/00672700109511701

West, P., and D. Brockington. 2006. An anthropological perspective on some unexpected consequences of protected areas. Conservation Biology 20(3):609-616. https://doi.org/10.1111/ j.1523-1739.2006.00432.x

West, P., J. Igoe, and D. Brockington. 2006. Parks and peoples: the social impact of protected areas. Annual Review of Anthropology 35:251-277. https://doi.org/10.1146/annurev. anthro.35.081705.123308

Western, D., S. Russell, and I. Cuthill. 2009. The status of wildlife in protected areas compared to non-protected areas of Kenya. PLoS Biology 4(7):e6140. https://doi.org/10.1371/journal. pone. 0006140

Western, D., and J. Waithaka. 2005. Policies for reducing human - wildlife conflict: a Kenya case study. Pages 357-372 in R. Woodroffe, S. Thirgood, and A. Rabinowitz, editors. People and wildlife, conflict or co-existence? Cambridge University Press, Cambridge, UK. https://doi.org/10.1017/CBO9780511614774.023

Western, D., J. Waithaka, and J. Kamanga. 2015. Finding space for wildlife beyond national parks and reducing conflict through community-based conservation: the Kenya experience. Parks 21:1. https://doi.org/10.2305/IUCN.CH.2014.PARKS-21-1DW. en

Western, D., and R. M. Wright. 1994. Natural connections: perspectives in community-based conservation. Island, Washington, D.C., USA.

Witter, R. 2013. Elephant-induced displacement and the power of choice: moral narratives about resettlement in Mozambique's Limpopo National Park. Conservation and Society 11(4):406-419. http://dx.doi.org/10.4103/0972-4923.125756 
Appendix 1. Additional primary evidence.

Additional (select) quotes from interviews and excerpts from primary documents (not included in the main manuscript) are presented below. The evidence (from interview and documents) has been organized by themes within each of the eras and attributes investigated. Quotes are first summarized under the "Era" heading. Then, each quote/excerpt is ordered under the heading that identifies the interaction between the attribute investigated and the thematic finding of the paper.

The attributes investigated include actors involved, decision-making process, formal rules, legal instruments and policies, and actors involved. Thematic findings include legacies of contested worldviews, the disproportionate influence of international organizations, and structures of power: accountability of institutions and devolution of authority.

\section{$\underline{\text { National Parks 1945-1975 }}$}

\section{Actors involved - The disproportionate influence of international organizations}

"The trust land Board shall consist of the following members- $\{$ a) the person for the time being lawfully discharging the functions of Chief Commissioner, who shall be chairman; (b) two Africans who are elected members of the Legislative Council of Kenya. appointed by the Governor; (c) one European who is an elected member of the Legislative Council of Kenya, appointed by the Governor; (d) two other persons appointed by the Governor." (p 1091 Kenya Gazette Supplement No 93, 1960)

"The presence of internationally-known figures among the Trustees will facilitate donations from abroad" (p 5 Republic of Kenya 1975)

\section{Decision-making process - The disproportionate influence of international organizations}

"12. (1) There is hereby established a Board, to be known as the Central Land Advisory Board, which shall consist of - $(a)$ the Minister for the time being responsible for land, who shall !be chairman; $(b)$ the Commissioner of Lands, who shall be deputy chairman; and

(c) (i) eight Africans; (ii) five Asians; (iii) one Arab; and (iv) six Europeans; all of whom shall be appointed by the Governor. in his discretion." (p 1093 Kenya Gazette Supplement No 93, 1960)

\section{Decision-making process - Structures of power: accountability of institutions and devolution of authority}

"This centralization of responsibility will permit more flexible management of wildlife, particularly in those extensive areas which are integral components of the ecological units which contain National Parks and County Council Game Reserves" (p 4 Republic of Kenya 1975)

Formal rules, legal instruments and policies - Structures of power: accountability of institutions and devolution of authority 
"All land in Kenya is hereby declared to either be Crown land or private land or trust land" (p 1091 Kenya Gazette Supplement No 93, 1960)

\section{Centralized Power 1976-1988}

\section{Actors involved - Structures of power: accountability of institutions and devolution of authority}

"that was the early 1970 but because of various political pressures on the president at that time and this was Jomo Kenyatta he unilaterally, before this process was complete, declared a 200 sq mile national park. Which would have denied the maasai all of their dry season grazing," [\#8 KWS]

\section{Decision making process - The disproportionate influence of international organizations}

"Finally, wildlife is a major resource base for recreation and tourism. Tourism, largely based on wildlife, is among Kenya's top three foreign exchange earners" (p 49, IUCN World conservation strategy, 1980)

\section{$\underline{\text { KWS - 1989-2003 }}$}

\section{Actors involved - Legacies of contested worldviews}

"render services to the farming and ranching communities in Kenya necessary for the protection of agriculture and animal husbandry against destruction by wildlife." (p 1262, Republic of Kenya, 1989)

\section{Actors involved - The disproportionate influence of international organizations}

"I don't want to personalize it but I watched a whole lot of elephant being killed up there, it was pretty grim, you know you see the thing and you get more aggressive in nature, and you are armed but you realized you don't have the capacity to go out and fight these guys with A-Ks. I had a wealthy Norwegian friend, we were talking, he said I will give you the money if you persuade that community" [\#6-NGO]

"3B. (1) The Service shall be managed by a Board of Trustees of the Service which shall, subject to section 3c, consist of-- (a) a chairman appointed by the President; (b) the Permanent Secretary in the Ministry for the time being responsible for matters ,relating to wildlife; (c) the Permanent Secretary in the Ministry for the time being responsible for finance; (d) the Permanent Secretary in the Ministry for the rime being responsible for local government; (e) the Commissioner of Police; (f) the Director of Forests; (g) a representative of the Permanent Secretary in the 'Office of the President responsible for internal security; (h) the Director of Veterinary Services; (i) not more ,than six other trustees to be appointed by ,the Minister from amongst persons who are conversant with nature conservation in all its aspects." (p 1262, Republic of Kenya, 1989)

\section{Decision making process - The disproportionate influence of international organizations}


"Now that CWS has accomplished some of its objectives, especially in terms of reorienting attitudes, developing an approach to working with communities, and establishing a curriculum for training in community wildlife management, it is an appropriate time to reassess staffing needs and the future role of CWS in implementing specific aspects of the community wildlife program." (p 4 COBRA, 1996)

\section{Formal rules, legal instruments and policies - The disproportionate influence of international organizations}

"The US Agency for International Development initiated an innovative effort to assist the Government of Kenya through the Kenya Wildlife Service to establish and institutionalize a national program in community-based wildlife conservation and management." (p 1, COBRA, 1996)

"By 1992, he had persuaded the World Bank to give KWS a 5 year \$143 million loan to underwrite a Protected Area Wildlife Service program (PAWS), whose goals were to rehabilitate Kenya's national parks and, more urgently, to halt elephant and rhino poaching and banditry" (p 510, Science Magazine, 1998)

\section{Formal rules, legal instruments and policies - Structures of power: accountability of institutions and devolution of authority}

" $3 \mathrm{~A}$. The functions of the Service shall be to- $(0)$ formulate policies regarding the conservation. management and utilization of all types of fauna (not being domestic animals) and flora" (p 1260 Republic of Kenya, 1989)

\section{Conservancy Emergence - 2004-2016}

\section{Actors involved - Legacies of contested worldviews}

"Partnerships, by their very nature, represent a sustained commitment to move forward together to reach a higher common objective. To ensure an inclusive partnership and stakeholder involvement in decision making, ways must be found to (a) ensure wide representation from across the private sector and civil society organisations and (b) ensure that community voices are brought forward. This is because private sector, civil society actors and communities play a central role in environmental conservation and management" (p 48, National Environmental Policy, 2014)

\section{Actors involved - The disproportionate influence of international organizations}

"These non-state actors have the advantage of being more independent of political pressures than governmental formal management agencies. Thus they are well positioned to play an important leading role in agenda setting and policy development processes. For example, NGOs can mediate in the resolution of resource conflicts at the local level by bringing considerable 
expertise and resources. At the national level, they can inform and shape the public debate on environmental protection issues and challenges. “ (p 48, National Environmental Policy, 2014)

"actually it was TNC that funded it, went down to Namibia to look at the conservancy model there and one of the things they came back with the need to create an umbrella organization that would represent sort of the interests of conservancies" [\#5 - NGO]

\section{Decision making process - The disproportionate influence of international organizations}

"The need for decentralization and devolution of wildlife management to the lowest level possible and enlist the participation of the private sector, non-governmental organizations (NGOs), community based organizations (CBOs) and other non-state actors" ( $\mathrm{p} 4$, Republic of Kenya, 2012)

\begin{tabular}{|l|l|l|l|}
\hline $\begin{array}{l}\text { Agro climatic } \\
\text { Zone }\end{array}$ & $\begin{array}{l}\text { Potential land use } \\
\text { i-iii }\end{array}$ & $\begin{array}{l}\text { Area in } \\
\text { Ha }\end{array}$ & $\begin{array}{l}\% \text { of the } \\
\text { total land }\end{array}$ \\
\hline iv-v & $\begin{array}{l}\text { Margium to high: Agriculture, livestock (intensive), } \\
\text { crops), forestry, livestock } \\
\text { (ranching) and wildlife conservation }\end{array}$ & 8600 & $15 \%$ \\
\hline vi-vii & $\begin{array}{l}\text { Marginal, livestock } \\
\text { (extensive pastoralism) and wildlife conservation }\end{array}$ & 37,400 & $65 \%$ \\
\hline
\end{tabular}

(p 60, National Spatial Plan Republic of Kenya, 2015)

\section{Formal rules, legal instruments and policies - Structures of power: accountability of institutions and devolution of authority}

"Chapters four to eleven comprise the all inclusive policy framework for sustainable wildlife conservation countrywide. Some of the key elements include: (1) enactment of a comprehensive wildlife law to implement this Policy; (2) mainstreaming of wildlife conservation into national land use systems; (3) decentralization of wildlife conservation planning, implementation and decision-making processes to the constituency level; (4) wildlife conservation and management will be ecosystem-based; (5) community participation in wildlife conservation and management through establishment of community wildlife conservation areas and sanctuaries; (6)

mainstreaming research and monitoring in wildlife conservation and management; (7) provision of appropriate incentives and user rights to communities and other stakeholders to promote sustainable wildlife conservation and management; (8) innovative measures to mitigate human wildlife conflict; (9) establishment of the Wildlife Compensation Fund to broaden the financial resource base for compensation of wildlife damage to human, crop, livestock and property; and (10) regional and international cooperation in the conservation and management of shared wildlife resources." (p 2-3, Republic of Kenya, 2007) 
“(c) Vest renewable resources such as wildlife, water and public forests in the State to hold in trust for the people of Kenya" ( $p$ 22, Republic of Kenya, 2009) 